\title{
Enhancing Critical Thinking Through CALLA In Developing Writing Ability Of EFL Students
}

\author{
Huzairin \\ University of Lampung \\ Hery Yufrizal \\ University of Lampung
}

\begin{abstract}
The objectives of this research are firstly to investigate the application of Cognitive Academic Language Learning Approach in improving students' English writing ability andsecondly to answer what factors influence the students' writing performance. The subjects of the research were the students of senior high schools in Indonesia consisting of a group of students as experimental group and as control group. The results showed that students improved their writing after they were involved in Cognitive Academic Language Learning Actvitities. Furthermore, the study also showed that levels of students' critical thinking did not any significant effects toward their writing achievement
\end{abstract}

\section{INTRODUCTION}

Many studies have revealed that learners from different cultures may learn a foreign language in differentways. The students learning a foreign language in Asian contexts used different learning strategies compared to students that learn the same language in Western context (Setiyadi, et al 2016). Cognitive Academic Language Learning Approach (CALLA)combines English language development with contentbased ESL and with instruction in special learner strategies that will help students understand and remember important concepts (Chamot and O’Malley, 1987).

Since English is taught as a foreign languagein Indonesia, the implementation of CALLA might be different from the original one. Therefore, this study attempts to modify the procedures or steps in CALLA in order it can be applicable in the language classroom. The modification includes the use of specific strategy (i.e. metacognitive strategies), the learning activities and the learning materials selected and applied by the teacher.

This paperintends to investigate whether or not there is any significant effect of modified CALLA on the use of metacognitive strategies and students' writing achievement before and after conducting the treatment at the second grade students of a private high school in Indonesia.This study tries tofind outwhether or not there is any significant effect of students' critical thinking level on their writing achievement.

\section{THEORETICAL FRAMEWORK}

CALLA combines English language development with content based ESL and with instruction in special learner strategies that will help students understand and remember important concepts (Chamot and O'Malley, 1987). Chamot and O'Malley (1987) furthermore pointed out that second language methods can be based on a syllabus (or a curriculum) or on a theory of learning processes and instructional procedures and that many current methodological 
approaches reflect one assumption but not the other. CALLA makes these two approaches to language teaching methods interdependent by integrating language learning and teaching theory and the specification of content to be taught.

Richards (1984)indicated the importance of addressing the needs of second language learners in program planning. CALLA is designed to meet the educational needs of three types of LEP students: (a) students who have developed social communicativeskills through ESL or exposure to an English-speaking environmentbut who have not developed academic language skills appropriate to their grade level; (b) students exiting from bilingual programs who need assistance in transferring concepts and skills learned in their native language to English; and (c) bilingual, English dominant students who are even less academically proficient in their native language than in English and need to develop academic English language skills.

Chamot and O'Malley (1987) stated CALLA is intended for students at the intermediate and advanced levels of English proficiency who need additional experiences in English language development specifically related to three academic areas: science, mathematics, and social studies

Figure 1.framework for strategies instruction cited in Amin, et al., 2011

Teacher Responsibility

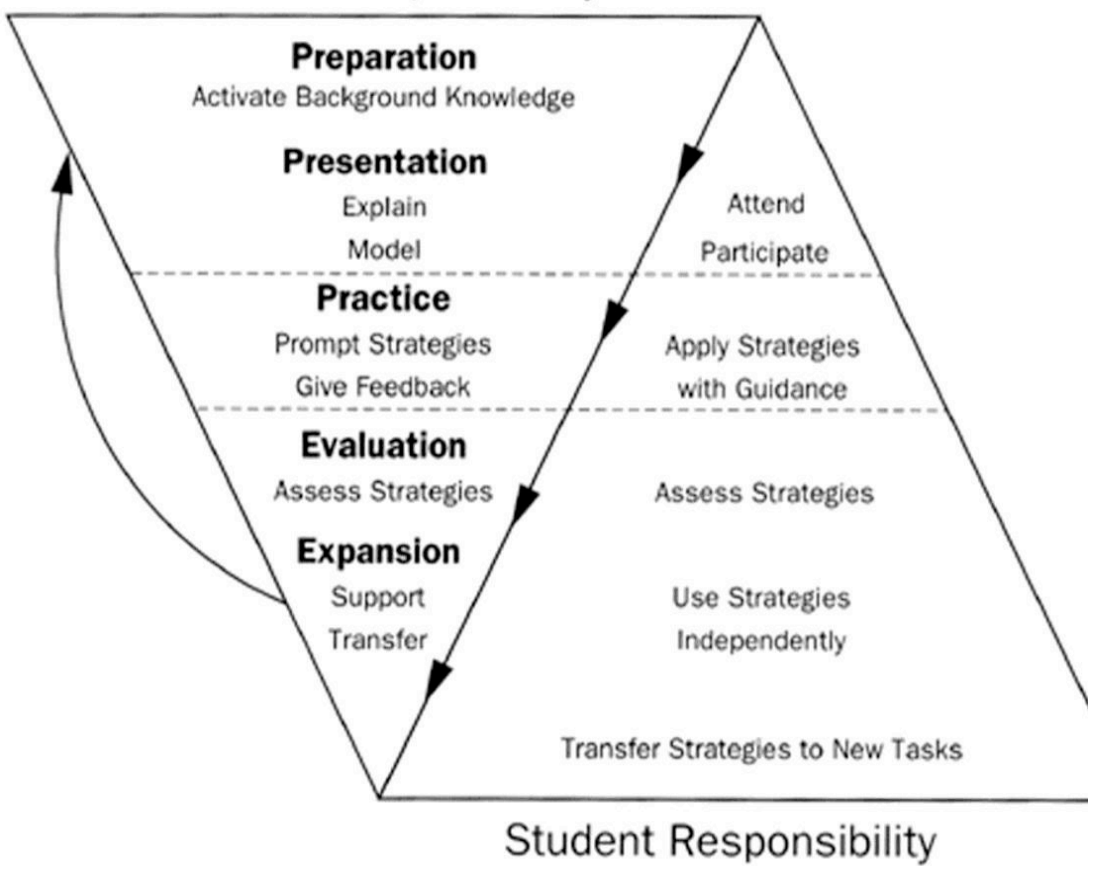

According to Chamot and O'Malley (1987) the CALLA model has three components: (a) a curriculum correlated with mainstream content areas, (b) English language development integrated with content subjects, and (c) instruction in the use of learning strategies.

Content-based English language development is not onlyimportant for developing academic language skills, but it is alsoinherently more interesting to many students than ESL classeswhich focus on language only. Content areas such as science,mathematics, and social studies present numerous topics related toa variety of personal interests. LEP students can be motivated notonly by the topics presented but also by knowing that they are developing the concepts and skills associated with these subjects - in other words, that they are actually doing 
"real" school work instead of merely learning a second language for applications that have yet to be revealed.

To select content topics for CALLA lessons, ESL teachers can coordinate with classroom teachers and consult subject-area textbooks for the grade level concerned. Classroom teachers can identify the most important concepts and skills taught in the content areas they teach. Science, mathematics, and social studies textbooks can be used as a source of specific information to be presented. Having used these resources to identify lesson topics, the ESL teacher can build language development activities onto the content information selected.

To sum up, the CALLA content-based curriculum is based on authentic subject matter from the mainstream curriculum which has been selected as central to the concepts and skills that are developed at particular grade levels.

The purpose of English language development, the secondcomponent of the CALLA model, is to provide students withpractice in using English as a tool for learning academic subjectmatter. Reading and language arts can be taught as part of contentareasubjects such as social studies, mathematics, and science. Thelanguage demands of the different content subjects, which includethe language of curriculum materials and of classroom participation,need to be analyzed so that students can be taught the actuallanguage functions, structures, and subjectspecific vocabulary thatthey will need when they enter the mainstream content class. Theselanguage demands, which are different from those of thebeginning-level ESL class or the type of language used for socialinteraction, need to be specifically taught and practiced in thecontext of actual subject-matter learning.

The following aspects of language should be included in the language development component of the CALLA model (Chamot, 1985): development of the specialized vocabulary and technical terms of each content area; practice with the language functions used in academic communication, such as explaining, informing, describing, classifying, and evaluating; development of the ability to comprehend and use the language structures and discourse features found in different subject areas; and practice in using thelanguage skills needed in the content classroom, such as listening to explanations, reading for information, participating in academic discussions, and writing reports. By integrating these types of language activities with grade-appropriate content, a curriculum based on the CALLA model can provide LEP students with the conceptual knowledge and language skills they will need to participate successfully in the mainstream classroom.

The CALLA model uses learning strategy instruction as anapproach to teaching the contentbased language developmentcurriculum described in the preceding sections. Learning strategyinstruction is a cognitive approach to teaching that helps studentslearn conscious processes and techniques that facilitate thecomprehension, acquisition, and retention of new skills andconcepts. The use of learning strategy instruction in secondlanguage learning is based on four main propositions (see Chipman,Sigel, \& Glaser, 1985; Derry \& Murphy, 1986; Weinstein \& Mayer,1986).

1. Mentally active learners are better learners. Students who organize new information and consciously relate it to existing knowledge should have more cognitive linkages to assist comprehension and recall than do students who approach each new task as something to be memorized by rote learning.

2. Strategies can be taught. Students who are taught to use strategies and provided with sufficient practice in using them will learn more effectively than students who have had no experience with learning strategies. 
3. Learning strategies transfer to new tasks. Once students have become accustomed to using learning strategies, they will use them on new tasks that are similar to the learning activities on which they were initially trained.

4. Academic language learning is more effective with learning strategies. Academic language learning among students of English as a second language is governed by some of the same principles that govern reading and problem solving among native English speakers.

Studies in learning strategy applications indicate that students taught to use new strategies can become more effective learners (O'Malley, 1985). In a recent experimental study, second language learners were taught to use learning strategies for vocabulary, listening comprehension, and formal speaking tasks using academic content (O'Malley, Chamot, Stewner-Manzanares, Russo, \&Küpper, 1985). The results showed that learning strategy instruction was most effective for the more integrative language tasks which involved the use of academic language skills to understand or produce extended text.

The lessons in the original CALLA are divided into five phases: Preparation, Presentation, Practice, Evaluation, and Follow-Up Expansion (Chamot and O’Malley, 1987).

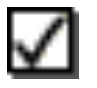

In the Preparation phase, teachers provide advance organizers about the lesson, and students identify what they already know about a topic, using elaboration as a strategy.

$\square$

In the Presentation phase, teachers provide new information to students, using techniques which make their input comprehensible. Teachers can use advance organizers and encourage the use of selective attention, self-monitoring, inferencing, summarizing, and transfer.

$\square$

In the Practice phase, students engage in activities in which they applylearning strategies, often in cooperative small-group sessions. During this phase, the teacher should encourage the use of strategies such as grouping, imagery, organizational planning, deduction, inferencing, and questioning for clarification.

$\square$

In the Evaluation phase, students reflect on their individual learning and plan to remedy any deficiencies they may have identified.

$\square$

Finally, in the Follow-Up Expansion phase, students are provided with opportunities to relate and apply the new information to their own lives, call on the expertise of their parents and other family members, and compare what they have learned in school with their own cultural experiences.

Setiyadi, et al (2016) emphasizes numerous studies have revealed that learners from different cultures may learn a foreign language in differentways. The students learning a foreign language in Asian contexts have been proved to use different learning strategies compared to students that learn the same language in Western countries. By identifying how the use of English learning strategies is correlated to their language skills, language teachers in the country may expect their students to learn a foreign language more successfully. Language teachers can condition their teaching processes in order for their students to use their effective strategies or training their students to use the strategies when language learners learn individual skill (Setiyadi, et al, 2016). 
As stated before that The Cognitive Academic Language Learning Approach (CALLA) is designed for Limited English Proficient (LEP) students who are being prepared to participate in mainstream content-area instruction (Chamot and O'Malley, 1987). Due to Indonesia students are categorized as Limited English Proficient (LEP) students, it means that CALLA can be implemented in Indonesia. Chamot and O'Malley (1987) add CALLA provides transitional instruction for upper elementary and secondary students at intermediate and advanced ESL levels. Related to this, the implementation of CALLA definitely will be different from the original one since English is taught as foreign language or EFL context in Indonesia. Hence, the researcher will modify the procedures or steps in CALLA in order it can be applicable in the language classroom. The modification not only will be on the use of specific strategy that is metacognitive strategies but also the learning activities and the learning materials which are selected and applied by the teacher.

Five lesson phases of the modified CALLA can be illustrated as follows:

Preparation: The purpose of this phase was to help students identify the strategies they are already using and to develop their metacognitive awareness of the relationship between their own mental processes and effective learning.

Activities: discussions about learning strategies that students already use for specific tasks, small group interviews in which students describe and share their special techniques for completing a task successfully.

$\checkmark$

Presentation: This phase focused on modeling the learning strategy. Learners were explicitly taught about the variety of strategies to use when they do not know a vocabulary word they encounter in paragraph writing. But more importantly, they received explicit instruction on how to use these strategies.

Activities: modeling how to use metacognitive strategies in writing skills with a specific academic task, giving the strategy a name (metacognitive strategies) and referring to it consistently by that name, explaining to the students how the strategy (metacognitive strategies) will help them in composing a paragraph writing and describing when, how and for what kinds of tasks they can use the strategy.

Practice: In this phase, students had the opportunity of practicing the learning strategies with an authentic learning task. They were asked to make conscious effort using the metacognitive strategies.

Activities: integrating critical thinking activity in language teaching through "practice" step of modified CALLA, for example, 1) developing a critical mindset, 2) opinion and reason generator, 3) critical questioning, 4) recognizing context, and 5) practicing the language for expressing critical thinking.

Self-evaluation: The main purpose of this phase was to provide students with opportunities to evaluate their own success in using learning strategies, thus developing their metacognitive awareness of their own learning processes.

Activities: debriefing discussions after using strategies (metacognitive strategies), comparing their own performance on a task completed without using metacognitive strategies and a similar task in which they applied the strategies, and open-ended questionnaires in which students expressed their opinions about the usefulness of metacognitive strategies.

Expansion: In this final phase students were encouraged to: a) use the strategies that they found most effective, b) apply these strategies to new contexts, and c) devise their own individual combinations and interpretations of metacognitive learning strategies. 
Activities: praise for independent use of metacognitive strategies, thinking skills discussions in which students brainstorm possible uses for metacognitive strategies they are learning, and follow-up activities in which students apply metacognitive strategies to new tasks and contexts.

\section{RESEARCH PROCEDURES}

This research was conducted in six meetings. The first meeting was used to distribute Academic Potency Test (APT) to classify the students' level of critical thinking in term of: Low, Middle, and High. Pre Test was administered on the second meeting. The treatment was employed in three meetings during the third meeting to the fifth meeting:1) The firstmeetingwas Preparation Step and Presentation Step, 2)The second meeting was Practice Step, and 3) The third meeting was Evaluation Step and Expansion Step. Moreover, Post Test was done on the sixth meeting. The limitation of time allocation in teaching English subject at the school became the consideration of researcher to divide five steps of CALLA into three meetings. The following was the clear explanation about the implementation of modified CALLA in language classroom.

\section{Preparation Step}

In Preparation Step, the teacher asked students to identify the strategy that had already been used for writingtask.The purpose of this step was to help students identify the strategies they were already using and to develop their metacognitive awareness of the relationship between their own mental processes and effective learning. For the activities, the teacher had discussions about learning strategies that students already use for specific tasks and did small group interviews in which students describe and share their special techniques for completing a task successfully.

During this step, most of the students did not use any types of certain strategies when they composed paragraph writing. Basically, they wrote their ideas directly. If they had idea they organized it in form of paragraph. They did not list or made an outline of their ideas. In addition, since the researcher was going to promote metacognitive strategies, most of the students were curious about the strategies proposed by the researcher that can be employed by the students to help them in writing tasks.

\section{Presentation Step}

In Presentation Step, the teacher introduced the new strategy namely metacognitive strategies. The teacher explained and gave modeling of the new strategy. Then she described the characteristics, usefulness, and application of this strategy. This step focused on modeling the learning strategy. Learners were explicitly taught about the variety of strategies to use when they did not know a vocabulary word they encountered in paragraph writing. But more importantly, they received explicit instruction on how to use these strategies. For the activities, the teacher provided a model how to use metacognitive strategies in writing skills with a specific academic task, gave the strategy a name (metacognitive strategies) and referred to it consistently by that name, explained to the students how the strategy can help them in composing a paragraph writing and described when, how and for what kinds of tasks they can use the strategy.

During this step, most students took a note of the illustration and explanation from the teacher. Furthermore, most of them askedsome questions related to how to use metacognitive strategies in writing tasksand related to the differences of each type of metacognitive strategies in terms of: planning strategy, monitoring strategy and evaluating strategy. 


\section{Practice Step}

In Practice Step, the teacher provided opportunities for strategy practice with an authentic learning tasks guided by the teacher. Besides that, she also integrated critical thinking activity for example, 1) developing a critical mindset, 2) critical questioning, 3) opinion and reason generator, 4) recognizing context, and 5) practicing the language for expressing critical thinking. In this step, students had the opportunity of practicing the learning strategies with an authentic learning task. They were asked to make conscious effort using the metacognitive strategies.

During this step, the students worked in pair to make paragraph writing. Theywere given twelve topics then they had to choose one topic. After choosing one topic, the students had to list their ideas, in terms of: definition, examples, their positions (agree/disagree), their arguments (negative/positive impacts of something), recommendation. They started to list their ideas in an outline then they organized them in form of paragraph writing (First Draft). The students exchanged their draft to their friends. The others checked and made correction on their friends' draft. After getting some feedback and input from their friends and teacher, the students had to revise their draft. Then, they rewrote their paragraph writing and rechecked their draft (Final Draft). Finally, the students made a comparison between their previous draft (in this case was Pre Test result) and their new draft. By comparing the results, they can see a lot of differences on their draft, especially related to the five writing aspects, in terms of: content, organization, vocabulary, grammar, and mechanic.

\section{Evaluation Step}

In Evaluation Step, the teacher asked the students to evaluate their success in using strategy. The teacher debriefed discussions after strategy practice. The main purpose of this step was to provide students with opportunities to evaluate their own success in using learning strategies, thus developing their metacognitive awareness of their own learning processes. For the activities, the teacher debriefed discussions after using strategies, compared their own performance on a task completed without using metacognitive strategies and a similar task in which they applied the strategies, and open-ended questionnaires in which students expressed their opinions about the usefulness of metacognitive strategies.

During this step, the students do self-reflection on their individual learning to evaluate the use of metacognitive strategies. They have to realize how far they have been using those strategies (planning, monitoring, and evaluating) during the writing process in the language classroom. Moreover, the teacher discussed about the strategy they had already used and the students expressed their ideas/opinion about the advantage and benefit of metacognitive strategies itself.

\section{Expansion Step}

In Expansion Step, the teacher asked the students to transfer and apply their strategy to the new tasks. For the activities, the students praised for independent use of metacognitive strategies, elaborated thinking skills discussions in which students brainstorm possible uses for metacognitive strategies they were learning, and follow-up activities in which students applied metacognitive strategies to new tasks and contexts.

In this final step, the students were encouraged to use the strategies that they found most effective, employed these strategies to new contexts, and devise their own individual combinations and interpretations of metacognitive learning strategies. 


\section{RESULTS AND DISCUSSION}

Students' Pre Test and Post Test scores from writing test were calculated through descriptive statistics by using SPSS version 21. Paired Sample T- Test was administered to see if there was any statistically significant difference between their Pre Test and Post Test score of their writing achievement.

Table 1. Descriptive Statistical Values Concerning Pre Test and Post Test Scores of Students' Writing Achievement

Paired Samples Test

\begin{tabular}{|c|c|c|c|c|c|c|c|c|c|}
\hline & \multicolumn{5}{|c|}{ Paired Differences } & $\mathrm{t}$ & $\mathrm{df}$ & Sig. (2-tailed) \\
\hline & & \multirow[t]{2}{*}{ Mean } & \multirow[t]{2}{*}{$\begin{array}{c}\text { Std. } \\
\text { Deviation }\end{array}$} & \multirow[t]{2}{*}{$\begin{array}{l}\text { Std. Error } \\
\text { Mean }\end{array}$} & \multicolumn{2}{|c|}{$\begin{array}{c}95 \% \text { Confidence Interval } \\
\text { of the Difference }\end{array}$} & & & \\
\hline & & & & & Lower & Upper & & & \\
\hline Pair 1 & $\begin{array}{l}\text { PreTest - } \\
\text { PostTest }\end{array}$ & -16.6154 & 10.7177 & 1.4863 & -19.5992 & -13.6316 & -11.179 & 51 & .000 \\
\hline
\end{tabular}

The table shows the students' Pre Test and Post Test score had significant difference in their writing achievement. The result of Paired Sample T- Test indicated the influence of the treatment on the students' scores was significant, since the value of variable sig. (2-tailed) was .000. The analysis of the collected data showed statistically significant positive relationship between metacognitive strategy instruction through modified CALLA and improving students' writing achievement.

Students' Pre Test and Post Test scores from Metacognitive Strategy Use in Writing (MSUW) questionnaire were calculated through descriptive statistics by using SPSS version 21. Paired Sample T- Test was administered to see if there was any statistically significant difference between their Pre Test and Post Test score of their metacognitive strategies use.

Table 2 Descriptive Statistical Values Concerning Pre Test and Post Test Scores of Students' Metacognitive Strategies Use Paired Samples Test

\begin{tabular}{|c|c|c|c|c|c|c|c|c|c|}
\hline & \multicolumn{5}{|c|}{ Paired Differences } & \multirow[t]{3}{*}{$\mathrm{t}$} & \multirow[t]{3}{*}{$\mathrm{df}$} & \multirow[t]{3}{*}{ Sig. (2-tailed) } \\
\hline & & \multirow[t]{2}{*}{ Mean } & \multirow[t]{2}{*}{$\begin{array}{l}\text { Std. } \\
\text { Deviation }\end{array}$} & \multirow[t]{2}{*}{$\begin{array}{l}\text { Std. Error } \\
\text { Mean }\end{array}$} & \multicolumn{2}{|c|}{$\begin{array}{c}95 \% \text { Confidence Interval of } \\
\text { the Difference }\end{array}$} & & & \\
\hline & & & & & Lower & Upper & & & \\
\hline Pair 1 & $\begin{array}{l}\text { PreTest - } \\
\text { PostTest }\end{array}$ & -.87019 & .33196 & .04603 & -.96261 & -.77777 & -18.903 & 51 & .000 \\
\hline
\end{tabular}

As seen in Table 2, the students' Pre Test and Post Test score had significant difference in their use of metacognitive strategies. The result of Paired Sample T- Test showed the influence of the treatment on the students' scores was significant, since the value of variable sig. (2-tailed) was .000. The analysis of the collected data revealed statistically significant positive relationship between metacognitive strategy instruction through modified CALLA and improving students' metacognitive strategies use.

\section{The Result of Students' Critical Level Effect toward Students' Writing Achievement}

After classifying the students into three level of critical thinking (low, middle, and high), then this study dealt with the effect of students' critical thinking level on their writing achievement. Furthermore, Univariate Analysis of Variance (One Way Anova) was used to investigate whether or not there is significant effect of students' critical thinking level on their writing achievement. The following table was the estimated marginal means of writing aspect regarding to students' level of critical thinking: 
Table 3.The Means Score of Writing Aspect regarding to Students' Level of Critical Thinking Descriptive Statistics

\begin{tabular}{|lc|c|c|c|}
\hline & CT & Mean & Std. Deviation & $\mathrm{N}$ \\
\hline \multirow{4}{*}{ Content } & 1.00 & 24.4412 & 1.30961 & 17 \\
& 2.00 & 25.0323 & 1.34124 & 31 \\
& 3.00 & 23.2500 & 2.59808 & 4 \\
& Total & 24.7019 & 1.49921 & 52 \\
& 1.00 & 16.3529 & 1.19589 & 17 \\
Organization & 2.00 & 16.3065 & .97192 & 31 \\
& 3.00 & 14.9500 & 1.79165 & 4 \\
& Total & 16.2173 & 1.15329 & 52 \\
& 1.00 & 15.9706 & 1.25587 & 17 \\
Vocabulary & 2.00 & 16.2903 & 1.02286 & 31 \\
& 3.00 & 15.2500 & 2.06155 & 4 \\
& Total & 16.1058 & 1.20186 & 52 \\
& 1.00 & 19.4706 & 1.76308 & 17 \\
Grammar & 2.00 & 19.5000 & 1.63299 & 31 \\
& 3.00 & 18.7500 & 2.39792 & 4 \\
& Total & 19.4327 & 1.70934 & 52 \\
& 1.00 & 3.9118 & .59254 & 17 \\
Mechanic & 2.00 & 3.9677 & .54674 & 31 \\
& 3.00 & 3.5000 & .81650 & 4 \\
& Total & 3.9135 & .58344 & 52 \\
\hline
\end{tabular}

Related to the table above, we can see the average scores of low critical thinker students(CT 1)after they got treatments. The average of content was (24.44), organizationwas (16.35), vocabularywas (15.97), grammar was (19.47), and mechanic was (3.91). Meanwhile, the average scores of middle critical thinker students (CT 2) in terms of contentwas(25.03), organizationwas (16.30), vocabulary was (16.29), grammar was (19.50), and mechanic was (3.96). Moreover, the average scores of high critical thinker students (CT 3): content was (23.25), organizationwas (14.95), vocabulary was (15.25), grammar was (18.75), and mechanic was (3.5).

Furthermore, this study also dealt with the effect of students' critical thinking level on their writing achievement. Then, Univariate Analysis of Variance (One Way Anova) was used to investigate whether or not there is significant effect of students' critical thinking level on their writing achievement.

\section{Table 4. Descriptive StatisticValues Concerning Writing Achievement regarding to Students' Level of Critical Thinking} ANOVA

\begin{tabular}{|l|c|c|c|c|c|}
\hline & Sum of Squares & Df & Mean Square & F & Sig. \\
\hline \multirow{3}{*}{ PostTest } & 114.843 & 2 & 57.422 & 1.850 & .168 \\
& 1521.214 & 49 & 31.045 & & \\
& 1636.058 & 51 & & & \\
\hline
\end{tabular}

As seen in Table 4, the means score of students' writing achievement had significant difference regarding to their level of critical thinking. However, the result of Univariate Analysis of Variance (One Way Anova) revealed the influence of the students' critical thinking levelin theirwriting scores was not significant, since the value of variable sig. (2-tailed) was .168. The analysis of the collected data showed statistically no significant impact of the students' critical thinking level toward their writing achievement. 
The third null hypothesis predicting that there is no significant effect of students' critical thinking level on their writing achievement was accepted. As the result showed the middle critical thinker students and the low critical thinker students got higher score rather than the high critical thinker students.

\section{CONCLUSIONS}

The training of metacognitive strategies has benefitsfor classroom practices since it can enrich the metacognitionprocess. Metacognitive strategies provide learnerswith the knowledge and ability to gather learningtools to carry out learning goals, and regarded as high order executive skills that make use of knowledge of cognitive processes and constitute an attempt to regulate ones' own learning by means of planning, monitoring, and evaluating.

The metacognitive strategies instruction promotes the learners' ability to select appropriate strategies for a particular task. These of metacognitive strategies increase the learners' awarenessof knowing why, when and how to employthese strategies to achieve the writing goals. Naturally, they will start to think metacognitively about the strategies they can use to improve their writing to become autonomous and strategic learners. In addition, to be a good writer, one needs not only task specific knowledge and skills, but also metacognitive awareness and knowledge.

Concerning the relationship between critical thinking and writing achievement, it was found that levels of students' critical thinking have no significant effects toward their writing achievement.There might be some underlying reasons which clarifythis phenomena. The possible reasons deal with language proficiency, component of learning, and students' motivation. The limitation of the language makes the argument in the student's writing unclear. Hence, it might have impact in their writing achievement.

\section{References}

Ahlsen, E. and Lundh, N. (2007).Teaching Writing in Theory and Practice: A Study of Ways of Working with Writing in the $9^{\text {th }}$ Grade. Unpublished Degree Project: Lararhogskolan Stockholm University.

Amin, et al (2011).The Effectiveness of Using an Explicit Language Learning Strategy-based Instruction in Developing Secondary School Students' EFL Listening Comprehension Skills. Benha University. Publication Date: 01 December 2011. Retrieved on February, 10 2016.

Anderson, N. J. (2005). L2 Strategy Research.In E. Hinkel (Ed.), Handbook of Research in Second Language Teaching and Learning (pp. 757-772). Mahwah, NJ: Lawrence Erlbaum Associates.

Azwar, S. (2008).The Qualityof the TesPotensiAkademik (TPA) 07A.JurnalPenelitiandanEvaluasiPendidikan, Vol, 12, No. 2, pp. 231-250.

Bazrafkan, N. and Bagheri, M. S. (2014). The Relationship between Critical Thinking, Autonomy and Writing Skill of the Iranian EFL Learners. International Journal of Language Learning and Applied Linguistics World (IJLLALW), Vol. 7, No. 3, pp. 379-392. EISSN: 2289---2737 \& ISSN: 2289---3245. Available at: www.ijllalw.org

Brown, H. D. (2004). Language Assessment: Principles and Classroom Practices. New York: Pearson Education, Inc.

Caroll, R. T. (1990). Students Success Guide - Writing Skills [Accessed $8^{\text {th }}$ October 2016]. Available at: http://www.skepdic.com/refuge/writingskills.pdf

Chamot, A. U. and O’Malley, J. M. (1987). The Cognitive Academic Language Learning Approach: A Bridge to the Mainstream. TESOL Quarterly, Vol. 21, No. 2, pp. 227-249.

Chamot, A. U. (1995). Implementing the Cognitive Academic Language Learning Approach: CALLA in Arlington, Virgina.The Bilingual Research Journal, Vol. 19, No. 3 \& 4, pp. 379-394.

Chen, X. and Xiao, G. (2016).A Survey Study of Chinese College Engineering Students' Use of Metacognitive Strategies in English Writing.Theory and Practice in Language Studies, Vol. 6, No.7, pp. 1390-1395. ISSN: 17992591. DOI: http://dx.doi.org/10.17507/tpls.0607.09. 
Coskun, A. (2010). The Effect of Metacognitive Strategy Training on the Listening Performance of Beginner Students.Novitas-ROYAL (Research on Youth and Language), Vol. 4, No. 1, pp. 35-50.

Desitawardhani, N. (2014). Improving Students' Skills of Writing Explanation Texts through Picture Series for the Grade XII Students of SMA Negeri 2 Sleman in the Academic Year of 2013/2014.Unpublished Thesis: Yogyakarta State University.

Fahim, M. and Ghamari, M. R. (2011). Critical Thinking in Education: Globally Developed and Locally Applied. Theory and Practice in Language Studies, Vol. 1, No. 11, pp. 1632-1638. ISSN: 1799-2591. DOI:10.4304/tpls.1.11.1632-1638.

Golpour, F. (2014).Critical Thinking and EFL Learners' Performance on Different Writing Modes.Journal of PanPacific Association of Applied Linguistics, Vol. 18, No. 1, pp. 103-119.

Guo, H. (2012). An Empirical Study on the Relation between Meta-cognitive Strategies and Listening Autonomous Learning Ability.Theory and Practice in Language Studies, Vol. 2, No. 11, pp. 2446-2451. ISSN: 1799-2591. DOI: 10.4304/tpls.2.11.2446-2451.

Guo, M. (2013).Developing Critical Thinking in English Class: Culture-based Knowledge and Skills. Theory and Practice in Language Studies, Vol. 3, No. 3, pp. 503-507. ISSN: 1799-2591. DOI:10.4304/tpls.3.3.503-507.

Huy, N. T. (2015).Problems Affecting Learning Writing Skillof Grade 11 at ThongLinh High School.Asian Journal of Educational Research, Vol. 3, No. 2, pp. 53-69. ISSN: 2311-6080. Available at: www.multidisciplinaryjournals.com.

Ibnian, S. S. K. (2011).Brainstorming and Essay Writing in EFL Class.Theory and Practice in Language Studies, Vol. 1, No. 3, pp. 263-272. ISSN: 1799-2591. DOI: 10.4304/tpls.1.3.263-272.

Jacob, et al (1993).Teaching ESL Writing. New York: Prentice Hall Regents.

Klimova, B. F. (2011). Evaluating Writing in English as a Second Language.Journal of Social and Behavioral, Vol. 8, pp. 390-394. DOI: 10.1016/j.sbspro.2011.11.074.

Marzban, A. and Barati, Z. (2016).On the Relationship between Critical Thinking Ability, Language Learning Strategies, and Reading Comprehension of Male and Female Intermediate EFL University Students.Theory and Practice in Language Studies, Vol. 6, No. 6, pp. 1241-1247. ISSN: 1799-2591. DOI:

http://dx.doi.org/10.17507/tpls.0606.14.

Marzban, A. and Jalali, F. E. (2016).The Interrelationship among L1 Writing Skills, L2 Writing Skills, and L2 Proficiency of Iranian EFL Learners at Different Proficiency Levels. Theory and Practice in Language Studies, Vol. 6, No. 7, pp. 1364-1371. ISSN: 1799-2591. DOI: http://dx.doi.org/10.17507/tpls.0607.05.

Muflikhati, A. (2013). Improving Students' Writing Skills on Recount Texts through the Use of Dialogue Journal Writing of the Tenth Grade Students of SMA IT Abu Bakar Yogyakarta in the Academic Year of 2012/2013.Unpublished Thesis: State University of Yogyakarta.

O'Hare, L. and McGuinness, C. (2009).Measuring Critical Thinking, Intelligence, and Academic Performance in Psychology Undergraduates.The Irish Journal of Psychology, Vol. 30, No. 3-4, pp. 123-131. ISSN: 0303-3910.

Purnomowati, D. A. (2010).Improving the Ability in Writing Hortatory Exposition Texts through a Group Discussion for Grade XI Students of Senior High School (An Experimental Research of Grade XI Students of SMA Negeri 3 Demak in the Academic Year of 2008/2009). Unpublished Thesis: Semarang State University.

Puspitasari, P. W. (2013). Improving Students' Skillsof Writing Hortatory Exposition Texts through Portfolio Assessment for the Eleventh Grade Studentsof SMA Negeri 4 Yogyakarta in the Academic Year of 2012/2013. Unpublished Thesis: State University of Yogyakarta.

Setiyadi, et al (1999).A Survey of Language Learning Strategies in a tertiary EFL in Indonesia. Paper Presented at the Australian Association for Research in Education (AARE) Annual Conference, Melbourne.

Setiyadi, Ag. (2006). MetodePenelitianuntukPengajaranBahasaAsing. Yogyakarta: PenerbitGrahallmu.

Setiyadi, et al (2016). How Successful Learners Employ Learning Strategies in an EFL Setting in the Indonesian Context. English Language Teaching, Vol. 9, No. 8, pp. 28-38. ISSN: 1916-4742. URL:

http://dx.doi.org/10.5539/elt.v9n8p28. Available at: elt.ccsenet.org.

Sun, L. (2013).The Effect of Meta-cognitive Learning Strategies on English Learning.Theory and Practice in Language Studies, Vol. 3, No. 11, pp. 2004-2009. ISSN: 1799-2591. DOI: 10.4304/tpls.3.11.2004-2009.

Utami, T. A. A. (2014). Improving the Ability in Writing Descriptive Texts through Brainstorming Technique for Grade VIII Students at SMP N 1 Piyungan. Unpublished Thesis: Yogyakarta State University. 
Wang, P. (2009). The Inter-rater Reliability in Scoring Composition.English Language Teaching, Vol. 2, No. 3, pp. 39-43. Available at: www.ccsenet.org/journal.html.

$\mathrm{Xu}$, J. (2011).The Application of Critical Thinking in Teaching English Reading. Theory and Practice in Language Studies, Vol. 1, No. 2, pp. 136-141. ISSN: 1799-2591. DOI: 10.4304/tpls.1.2.136-141.

Yulianti, N. (2014). Improving the Writing Skills through Diary Writing of the Tenth Grade Students of SMA N 1 Ngemplak.Unpublished Thesis: Yogyakarta State University.

Zhang, L. and Seepho, S. (2013). Metacognitive Strategy Use and Academic Reading Achievement: Insights from a Chinese Context. Electronic Journal of Foreign Language Teaching, Vol. 10, No. 1, pp. 54-69. Available at: http://eflt.nus.edu.sg/.

Zhao, N. (2009). Metacognitive Strategy Training and Vocabulary Learning of Chinese College Students.English Language Teaching, Vol. 2, No. 4, pp. 123-129. Available at: www. ccsenet.org/journal.html. 